\title{
Nacionalismo y Marxismo en el Partido Socialista Popular (1948-1957)
}

\author{
Nationalism and Marxism in the Chilean Popular Party (1948-1957)
}

\author{
Joaquín Fernández Abara*
}

Resumen: El artículo aborda las transformaciones vividas por el Partido Socialista Popular chileno entre los años 1948 y 1957. En consonancia con algunas nuevas interpretaciones, sostenemos que el proceso de radicalización socialista debe ser rastreado desde la década de 1950 y que tuvo su expresión en líneas estratégicas, programas y cambios en la política de coalición. Consideramos que dicho proceso de radicalización tuvo en sus orígenes un carácter nacionalista y que en su génesis jugó un papel fundamental la adaptación de elementos provenientes de movimientos nacionalistas latinoamericanos y de experiencias socialistas que remarcaron su carácter nacionalista.

Palabras Clave: Socialismo, Chile, Partido Socialista Popular, Nacionalismo, Antiimperialismo

\begin{abstract}
The article addresses the transformations experienced by the Chilean Popular Socialist Party between 1948 and 1957. In line with some new interpretations, we state that the process of socialist radicalization must be traced back to the 1950s and had its expression in strategic lines, programs and changes in coalitional politics. We consider that this process of radicalization had in its origins a nationalist character and that in its genesis played a fundamental role the adaptation of elements coming from Latin American nationalistic movements and socialist experiences that stressed their nationalistic character.
\end{abstract}

Key Words: Socialism, Chile, Popular Socialist Party, Nationalism, Antiimperialism

Recibido: 31 diciembre 2016

Aceptado: 20 marzo 2017 


\section{Introducción}

Buena parte de los estudios sobre la historia del Partido Socialista que han abordado la década de 1950, lo han hecho centrándose en acontecimientos y procesos que tuvieron lugar entre fines de dicha década y la del 60, como la gestación de la unidad socialistacomunista en el Frente de Acción Popular, los debates entre socialistas y comunistas en torno a sus líneas estratégicas y el influjo ejercido por la Revolución cubana ${ }^{1}$. Así, se ha tendido a prestar escasa atención a los fenómenos que tuvieron lugar a inicios de dicha década y a muchos de los cuales se les ha analizado en calidad de antecedentes, en función de desarrollos posteriores. Se trata un problema que no sólo es propio de los estudios históricos referidos al Partido Socialista, sino en general de la historiografía sobre Chile, la que, usualmente, no ha enfatizado el estudio de aquellos años.

Como contrapunto, consideramos que es necesario abordar las particularidades del período, teniendo en cuenta sus elementos de continuidad y cambio, evitando así aproximaciones teleológicas que no consideren los dilemas y alternativas que enfrentaron los actores estudiados. Para comprender dicha situación, debemos conocer las transformaciones que en ese entonces vivía el Partido Socialista Popular entre los años 1948 y $1957^{2}$. Con dicho fin, en primer lugar, analizaremos brevemente los cambios en la política coalicional del PSP hacia la década de 1950. Después, pasaremos a identificar los vínculos y modelos internacionales que los socialistas populares desarrollaron en aquellos años, analizando el modo en que fueron asimilados. Enseguida, estudiaremos los mecanismos a través de los cuales la dirigencia se encargó de difundir y dar a conocer aquellas

\footnotetext{
* Chileno. Profesor Investigador CIDOC-Escuela de Historia, Universidad Finis Terrae. Chile. Ph. D () Universidad de Leiden. Países bajos. jfernandez@uft.cl

${ }^{1}$ Muchos de los más completos e interesantes estudios sobre la historia de la izquierda y el Partido Socialista tienden a centrarse en explicar los sucesos de la década del 60. Al respecto, véase Julio Faúndez, Marxism and Democracy in Chile. From 1932 to the Fall of Allende (New Haven: Yale University Press, 1988); también la maciza descripción del debate estratégico de la izquierda desarrollado por Marcelo Casals, El alba de una revolución. La izquierda y la construcción estratégica de la vía chilena al socialismo. 1956-1970 (Santiago: Lom Ediciones, 2010) 75 y Benny Pollack y Hernán Rosenkraz, Revolutionary Socialdemocracy: The Chilean Socialist Party (Londres: Pinter, 1986). Otro estudio de gran calidad que centra su atención en el período inmediatamente anterior y no cubre completamente dicha década es el de Paul Drake, Socialism and Populism in Chile, 1932-1952 (Chicago-Londres: University of Chicago Press, 1978). Una contribución más reciente, desde el punto de vista de la historia conceptual e intelectual, es la de Camilo Fernández Carroza y Pablo Garrido González, "Progresistas y revolucionarios: el Frente de Acción Popular y la Vía Chilena al Socialismo, 1956-1967”. Izquierdas 31 (Diciembre de 2016) 71-101

${ }^{2}$ El Partido Socialista Popular fue la facción mayoritaria del Partido Socialista de Chile que se constituyó como partido en el año 1948, tras romper con los sectores anticomunistas del partido que votaron en el Congreso Nacional por la aprobación Ley de Defensa Permanente de la Democracia, que, entre otras medidas, ilegalizaba al Partido Comunista. Estos últimos sectores mantuvieron la denominación original del Partido, bajo el nombre del Partido Socialista de Chile. El Partido Socialista Popular se reunificó con el Partido Socialista de Chile, que ya había expurgado sus elementos anticomunistas a inicios de la década de 50, en el año 1957. Al respecto véase Marcelo Casals Araya, La creación de la amenaza roja. Del surgimiento del anticomunismo en Chile a la "campaña del terror" de 1964 (Santiago: Lom Ediciones, 2016) 187, Jorge Arrate y Eduardo Rojas, Memoria de la Izquierda Chilena (Santiago: Ediciones B, 2003) I 251-252, Carlos Huneeus, La guerra fría chilena. Gabriel González Videla y la Ley Maldita (Santiago: debate, 2009) 239-242 y Julio César Jobet, El Partido Socialista de Chile (Santiago: Ediciones Prensa Latinoamericana, 1971) I 210-214.
} 
experiencias. Luego examinaremos como dichas transformaciones influyeron el desarrollo de líneas estratégicas de carácter nacionalista revolucionario en el Partido Socialista Popular a mediados de la década de 1950, centrándonos en la labor cumplida por Oscar Waiss. Finalmente, señalaremos como la emergencia de las nuevas líneas estratégicas del Partido Socialista Popular en el año 1955 apuntaron, como objetivo central, a la construcción de un "Estado Nacionalista Revolucionario".

Como puede observarse, el análisis de los "procesos de transferencia política", esto es, la "migración" de prácticas e ideas políticas "a través de las fronteras nacionales y su uso como ejemplos", cumplen un rol fundamental en el enfoque a través del cual abordaremos el objeto de estudio ${ }^{3}$. Los estudios de transferencia se sitúan en el marco de la Historia Transnacional, entendiendo a esta como una perspectiva de análisis que plantea la necesidad de estudiar la historia integrando los procesos de vinculación e interconexión, tanto de índole cooperativa como conflictiva, entre actores de diverso tipo más allá de las fronteras nacionales. Dicho tipo de análisis y narración permite descentrar la mirada del reduccionismo de las narrativas históricas nacionalistas, que tienden a favorecer de manera casi exclusiva las explicaciones de carácter endógeno. Sin embargo, a la vez que nos permite insertar la realidad local en un contexto global, no deja de tener en cuenta los constreñimientos propios de las sociedades nacionales al momento de tratar el modo en que circulan las ideas ${ }^{4}$. Estas prevenciones se vuelven especialmente necesarias al estudiar períodos históricos en que el nacionalismo se volvió una fuerza política relevante y en que los movimientos antiimperialistas y de liberación nacional adquirieron un carácter modélico 5 .

De este modo, mostraremos como se produjo una recepción crítica de diversas experiencias políticas internacionales, las que fueron asumidas como modelos, sirviendo como ejemplos en el desarrollo de estrategias y lineamientos político-ideológicos en el ámbito nacional. Así aspectos como la política de coalición, los lineamientos estratégicos y la propia organización interna del Partido Socialista Popular, con sus instituciones e instancias de sociabilidad y difusión, se vieron afectadas por elementos tomados de dichas experiencias. En este sentido, consideramos que el estudio de los partidos políticos debe realizarse teniendo en cuenta las redes transnacionales, tanto de carácter formal como informal, en que estos se insertaban ${ }^{6}$.

\footnotetext{
${ }^{3}$ En este sentido, utilizamos la concepctualización de "political transfer" desarrollada por Henk Te Velde. Veáse Henk Te Velde, "Political Transfer: An Introduction". European Review of History 12 ( Julio de 2005) 205.

${ }^{4}$ Sobre la perspectiva Transnacional y como esta pretende integrar elementos que trascienden las fronteras nacionales sin olvidar la importancia de estas últimas, véase Bernhard Struck, Kate Ferris y Jacques Revel, "Introduction: Space and Scale in Transnational History". The International History Review 33:4 (2011) 576. Sobre los condicionantes sociales, incluyendo constreñimientos nacionales, en la circulación de las ideas véase Pierre Bordieu, "The social conditions of the international circulation of ideas". Richard Shusterman, Bourdieu. A critical reader (Oxford: Blackwell Publishers, 1999) 220-228.

${ }^{5}$ Eric Hobsbawm, Nations and Nationalism Since 1780. Programme, Myth, Reality (Cambridge: Cambridge University Press, 1990) 150-162.

${ }^{6} \mathrm{Al}$ respecto véase la introducción de Olga Ulianova al libro Redes políticas y militancias. La historia política está de vuelta (Santiago: USACH-Ariadna, 2009), donde realiza un balance de algunas nuevas tendencias en historia política y destaca la importancia de estudiar los problemas políticos nacionales a la luz de sus vínculos
} 
Planteamos que en el período comprendido entre los años 1948 y 1955, el Partido Socialista Popular vivió un proceso inicial de radicalización política, cuyos contenidos adquirieron un carácter nacionalista revolucionario. Sostenemos que, tras el alejamiento del centro político representado en el Partido Radical, los socialistas desarrollaron un proceso de reflexión y discusión política que derivaría en el replanteamiento de sus líneas estratégicas, las que cristalizaron a mediados de la década de 1950 en la formulación de la política del Frente de Trabajadores ${ }^{7}$. Si bien la tesis del Frente de Trabajadores fue formulada de manera explícita, por primera vez, en $1955^{8}$, algunos autores han sostenido que muchos de sus supuestos y fundamentos ya estaban presentes en el programa de 1947, redactado por Eugenio González ${ }^{9}$. En dicho documento se planteaba el imperativo de acortar etapas" en la transición al socialismo ${ }^{10}$, al defender la necesidad de que "las grandes transformaciones económicas de la revolución democrático-burguesa -reforma agraria, industrialización, liberación- nacional" fueran "realizadas" en los "países latinoamericanos, a través de la revolución socialista" ". En este sentido, adherimos a los planteamientos de los autores que sostienen que el proceso de radicalización del Partido Socialista, usualmente fechado en la década de 1960, debe ser rastreado más atrás, como una transformación paulatina que venía teniendo lugar desde fines de las administraciones encabezadas por el Partido Radical, y fuertemente asociadas al desencanto que trajeron aparejados los resultados de las experiencias de colaboración con estas. ${ }^{12}$

En aquellos años la política del PSP manifestó un rechazo constante a la posibilidad de entrar en coalición con el centro político, representado por el Partido Radical. Sin embargo, al mismo tiempo mostró apertura a la posibilidad de entablar alianzas circunstanciales con otras fuerzas políticas. Por otra parte, durante dicho período, se

internacionales. Estas tendencias se insertan en la renovación de los estudios de historia política que se ha venido produciendo en los últimos años. Al respecto, dos textos que presentan balances y agendas de investigación para el caso chileno son los de Cristina Moyano Barahona, "La historia política en el Bicentenario. Entre la historia del presente y la historia conceptual. Reflexiones sobre la Nueva Historia Política". Revista de Historia Social y de las Mentalidades 15:1 (2011) 227-245 y Danny Monsálvez Araneda, "La historia reciente en Chile. Un balance desde la nueva historia política". Historia 369 6:1(2016) 111-139.

${ }^{7}$ La tesis del Frente de Trabajadores sostenía que ante la inexistencia de una burguesía nacional, "consideraba agotada la experiencia de los frentes con la burguesía y los partidos burgueses", entendiendo por estos a las colectividades centristas, como el Partido Radical y la Falange, en cuanto dicho sector sería incapaz de promover reformas democráticas y antimperialistas. Véase "Por qué sostenemos la política del frente de trabajadores" Boletín del Comité Ejecutivo del Partido Socialista Popular 2, [Santiago] diciembre de $1955: 1$. Esto implicaba la imposibilidad de realizar la revolución en dos etapas - la democrático-burguesa y la socialista- y que por el contrario, el proceso revolucionario debía ser llevado adelante en una sola etapa, siendo liderado por los partidos obreros. Dicha tesis se antepuso a la línea estratégica del Frente de Liberación Nacional, propuesta por los comunistas desde 1952. Véase Faúndez 1988.

${ }^{8}$ Julio César Jobet, El Partido Socialista de Chile (Santiago: Ediciones Prensa Latinoamericana, 1971) II 19.

${ }^{9}$ Casals, El alba, 75.

${ }^{10}$ Casals, El alba, 75.

${ }^{11}$ Eugenio González Rojas, "Fundamentación teórica del programa del Partido Socialista”, en Julio Cesar Jobet y Alejandro Chelén Rojas, Pensamiento teórico y político del Partido Socialista (Santiago: Editorial Quimantú, 1972) 88-89.

${ }^{12}$ Luis Ortega Martínez, "La radicalización de los socialistas de Chile en la Década de 1960, en Universum N 23 Vol. 2, Talca, 2008, pp. 152-164 y Pablo Rubio Apiolaza, "La izquierda Chilena en la década de 1950. Socialistas, comunistas y sus contradicciones”, en Revista Palimpsesto 1 (2003). 
exacerbó el contenido antimperialista y nacionalista de su discurso y sus propuestas programáticas. Esta tendencia no era novedosa, y se encontraba presente desde el momento fundacional de la colectividad, especialmente gracias al influjo aprista y la apropiación del pensamiento indoamericanista asociado a este ${ }^{13}$. Sin embargo, con el fin de la segunda Guerra Mundial, la emergencia de la Guerra Fría y con la consiguiente declinación relativa de la importancia del antifascismo, dichos contenidos volvieron a vitalizarse y adquirir centralidad en su discurso. Esta situación se veía reforzada por la importancia que las experiencias revolucionarias de carácter nacionalista no comunista adquirieron en el Partido Socialista, esto dado el impacto generado por el ejemplo de las luchas de liberación anticolonial y la postura de permanente crítica que el Partido tuvo hacia la Unión Soviética. Por lo demás, como ha sostenido Alfredo Riquelme, en la década de 1950 "los actores nacionales que intentaban hacer política escapando de las opciones dicotómicas y del simplificador antagonismo global" de la Guerra Fría tuvieron importantes éxitos en Chile. Esto especialmente en el marco de un "contexto regional marcado por la retórica tercerista de los liderazgos populistas" ". En este sentido, la investigación sobre el socialismo chileno en el período de la Guerra Fría, y en especial del Partido Socialista Popular, nos ayuda a comprender la importancia que los conflictos entre el norte y el sur tuvieron en el imaginario de los actores chilenos, evitando la reducción histórica de la Guerra Fría a un conflicto entre el este y el oeste ${ }^{15}$.

El reforzamiento de los contenidos nacionalistas del discurso del Partido Socialista Popular se notó en diversas instancias. En primer lugar, en la generación de acercamientos a otras colectividades de carácter nacionalista en Chile, las que se encontraban aglutinadas en torno a la candidatura de Carlos Ibáñez del Campo, a inicios de la década de 1950. En segundo lugar, en el reforzamiento de la admiración y la creación de nuevos vínculos con otros movimientos y partidos políticos de carácter nacionalista en el tercer mundo, especialmente en Latinoamérica. En tercer lugar y en una situación que no ha sido indagada con la suficiente profundidad por la historiografía política del Partido Socialista, en el hecho que el Partido Socialista Popular llegase a definir su propia línea política como "Nacional Revolucionaria".

Con el fin de lograr nuestros objetivos, además de la bibliografía secundaria, utilizaremos prensa del período, informativa y partidista. En este último caso tendremos en cuenta tanto aquella destinada al público, como la de circulación interna. También analizaremos folletos y libros políticos del período, junto con textos de memorialistas.

\footnotetext{
${ }^{13}$ Sebastián Hernández Toledo, "Apristas en Chile: circuitos intelectuales y redes políticas durante los años 1930”. Revista de Historia y Geografía 31(2014) 77-94, Fabio Moraga Valle, “¿Un partido indoamericanista en Chile? La Nueva Acción Pública y el Partido Aprista Peruano”. Histórica, 33. 2 (2009) 109-156 y Juan Manuel Reveco, "La Influencia del APRA en el Partido Socialista de Chile”. Igualdad y Democracia 2 (2015), 71-84.

${ }^{14}$ Alfredo Riquelme Segovia, "La Guerra Fría en Chile: Los intrincados nexos entre lo nacional y lo global". Tanya Harmer y Alfredo Riquelme Segovia (Editores), Chile y la Guerra Fría Global (Santiago: Instituto de Historia de la Pontificia Universidad Católica de Chile -RIL Editores, 2014) 13-14.

${ }^{15}$ Véase la introducción de Tanya Harmer, Allende's Chile and the interamerican Cold War (Chapell Hill, The University of North Carolina Press, 2011). 1-19 y Hal Brands, Latin America's Cold War (Cambridge, Massachussets \& London: Harvard University Press, 2010), 3 y 7.
} 


\section{La política de coalición y el acercamiento a las fuerzas nacionalistas chilenas}

A inicios de la década de 1950, en el marco de una crisis de desafección que afectaba al sistema de partidos que adquirió tintes nacionalistas y autoritarios, el Partido Socialista vivió un acercamiento hacia fuerzas políticas de carácter ibañista y nacionalista. En el marco de su XIII Congreso Ordinario, el que tuvo lugar en junio de 1950, el Partido Socialista Popular se planteó una política de alianzas reluctante a entablar alianzas de largo alcance, especialmente con el Partido Radical, pero al mismo tiempo abierta al desarrollo de alianzas limitadas con otras fuerzas políticas "progresistas"16. En esta lógica, los socialistas populares adhirieron a la candidatura presidencial de Carlos Ibáñez del Campo con miras a las elecciones de 1952. Los socialistas populares justificaron su apoyo a la candidatura de Ibáñez sosteniendo que el ibañismo sería una fuerza política con amplio arraigo popular, antioligárquica y crítica del radicalismo y de la derecha, pero al mismo tiempo caracterizada por su inorganicidad y falta de contenidos doctrinarios claros, planteando que sería posible aprovechar dicho apoyo de masas y darle conducción, en un sentido socialista ${ }^{17}$. De este modo, negociaron su apoyo a Ibáñez a cambio de que este adoptara un "programa de acción gubernativa", que apuntaba a la realización de reformas de carácter nacionalista y antioligárquico, incluyendo medidas como la reorientación de la política internacional en un sentido antimperialista, el fin de la legislación represiva que afectaba al Partido Comunista y al movimiento sindical -incluyendo al del ámbito rural- desde el gobierno de Gabriel González Videla, el reforzamiento de las tendencias a la planificación estatal de la economía y la realización de una reforma agraria ${ }^{18}$. El apoyo del Partido Socialista Popular a Ibáñez generó críticas entre algunos de sus dirigentes, encabezados por Salvador Allende, la mayoría de las cuales se fundamentaron en el pasado dictatorial del candidato, en las características fascistas que se le atribuían a este y a sus bases de apoyo, en la heterogeneidad social de estas últimas y en su cercanía con el peronismo. Sin embargo, estas críticas fueron desestimadas por diversos dirigentes socialistas populares, siendo tachadas de pequeñoburguesas, liberales y europeizantes ${ }^{19}$. Así, los socialistas populares ingresaron a la

\footnotetext{
${ }^{16} \mathrm{Al}$ respecto véanse las resoluciones del XIII Congreso Ordinario del Partido Socialista Popular, el que tuvo lugar los días 2, 3 y 4 de junio de 1950 en Santiago, en donde se planteaba que "Dada la ausencia en estos momentos de una sincera afinidad programática entre el PSP y los otros partidos de avanzada, el Congreso del Partido estima ineficaz toda política de alianzas formales y permanentes y propicia, en cambio, una acción común con todas las agrupaciones de orientación progresista en cada caso y en todo terreno o esfera de acción en que sus esfuerzos converjan en un propósito colectivo" , en Julio César Jobet I 215.

${ }^{17}$ Una de las más interesantes síntesis de los términos de la argumentación de los sectores ibañistas en el Partido Socialista popular puede encontrarse en las memorias de Clodomiro Almeyda. Véase Clodomiro Almeyda, Reencuentro con mi vida (Santiago: Las Ediciones del Ornitorrinco, 1987) 122-124.

${ }^{18}$ Los términos de esta negociación pueden ser encontrados en El Mercurio [Santiago]15 de enero de 1951.

${ }^{19}$ Dicha situación llevó a que un pequeño grupo de militantes liderado por Salvador Allende, el que se oponía a la candidatura de Ibáñez, abandonase el Partido Socialista Popular creando el Movimiento de Recuperación Socialista, el que se uniría al Partido Socialista de Chile. Este último partido, en conjunto con un Partido Comunista en la ilegalidad, levantarían la candidatura presidencial de Salvador Allende en las elecciones de 1952. La controversia generada al interior del Partido Socialista a raíz del apoyo a la candidatura de Carlos Ibáñez del Campo ha sido tratada en Joaquín Fernández Abara, El ibañismo. 1937-1952. Un caso de populismo en la política chilena (Santiago: Ediciones del Instituto de Historia de la Pontificia Universidad Católica de
} 
Alianza Nacional del Pueblo, coalición de partidos y movimientos destinada a apoyar la candidatura y posteriormente el gobierno de Carlos Ibáñez del campo. En ella convivieron tanto con partidos políticos de carácter nacionalista y corporativista, como era el caso del Partido Agrario Laborista, como con una serie de pequeños movimientos "ibañistas" emergentes, los que, en general, representaban tendencias nacionalistas, personalistas y hasta cierto punto, autoritarias, y con otros partidos menores ${ }^{20}$.

Una vez que tuvo lugar el triunfo de Carlos Ibáñez del Campo, los socialistas participaron del Gobierno hasta octubre del año $1953^{21}$. Al retirarse del gobierno de Ibáñez, alegando decepción sobre sus políticas, los socialistas populares sostuvieron que muchos miembros del Gabinete no sólo habrían mostrado "vacilaciones", en los afanes de llevar adelante una política "dirigida realmente a destruir los privilegios de la oligarquía y a liberarnos de la presión imperialista"22. Incluso llegaron a denunciar "abiertas concomitancias con los grupos tradicionalmente enemigos de los trabajadores" 23 . Sin embargo, siguieron abiertos a la posibilidad de mantener alianzas con las fuerzas de carácter nacionalista que habían sostenido la campaña de Ibáñez, e incluso hicieron llamados a su unidad:

\begin{abstract}
$\mathrm{Al}$ retirarse del gobierno, el Socialismo Popular expresa el anhelo de las grandes mayorías nacionales por llevar adelante una firme política anti-oligárquica y antiimperialista y está seguro de que su intención será comprendida por el resto de los partidos que apoyaron al señor Ibáñez y que expresaron este mismo deseo durante su campaña electoral. Esta finalidad esencial no será jamás olvidada por nuestro partido, y ella es la que explica nuestra cooperación directa en el gobierno, a la que ahora hemos puesto término. Para cumplirla, el PSP hace un llamado a las fuerzas populares y nacionales que levantaron la campaña presidencial del señor Ibáñez y a todos los partidos y grupos de orientación progresista, seguro de que el curso natural de los procesos sociales llevará muy pronto a los trabajadores a expresarse mayoritariamente en una República Democrática de Trabajadores, que construya las bases de un sistema social en que encuentren satisfacción las más puras aspiraciones de los obreros, campesinos, empleados y sectores medios de la población ${ }^{24}$.
\end{abstract}

Chile, 2007) y del mismo autor, "Populismo, democracia y marxismo: el debate de la izquierda chilena y la candidatura presidencial de Salvador Allende en 1952". Finis Terrae. Revista de Humanidades 1, Tercera época (2013) 41-58.

${ }^{20}$ Sobre la Alianza Nacional del Pueblo véase Jaime Antonio Etchepare Jensen, "Ibáñez y su revolución de 1952". Política 26 (1991) $61-95$.

${ }^{21}$ Sobre la participación socialista en el segundo gobierno de Carlos Ibáñez del Campo, véase Tomás Moulian, Fracturas. De Pedro Aguirre Cerda a Salvador Allende (1938-1973) (Santiago: Lom, 2006) 158-162.

${ }^{22}$ Alejandro Chelén Rojas, Trayectoria del socialismo. Apuntes para una historia crítica del socialismo chileno (Buenos Aires: Editorial Austral, 1967) 137.

${ }^{23}$ Chelén 137.

${ }^{24}$ Chelén 137. 


\section{Los modelos internacionales entre el "sentido nacional del socialismo" y el "nacionalismo popular"}

En referencia a la creciente revalorización de las experiencias políticas extranjeras de carácter nacionalista, debemos tener en cuenta que la admiración del Partido Socialista Popular hacia las experiencias políticas nacionalistas del período se vio facilitada tanto por su rechazo al modelo soviético de socialismo como por su apoyo hacia experiencias socialistas autónomas de la órbita soviética y los "movimientos de descolonización"25.

En cuanto al rechazo del modelo soviético, muchos dirigentes e intelectuales socialistas, en especial Raúl Ampuero, Eugenio González y Julio Ce \{esar Jobet, utilizaron el concepto de "totalitario" para calificarlo, y la noción de "imperialismo" para caracterizar la política exterior de la Unión Soviética.

Ya en la fundamentación teórica del programa de 1947, redactada por Eugenio González, el Partido Socialista había asumido la necesidad de reforzar la "unidad continental" americana, defendiendo la "independencia nacional" y manteniéndose al margen de los bloques imperantes en el período incluyendo el soviético. Según el texto de González:

Los problemas económico-sociales tienen en la América Latina características que no se dan en el resto del mundo. Debemos plantearlos en términos positivos y buscar soluciones específicas sin subordinar nuestra posición revolucionaria a los fines políticos, económicos o estratégicos de ninguna de las grandes potencias que actualmente luchan por la hegemonía mundial.

No podemos estar con el imperialismo anglosajón ni con el expansionismo ruso. Debemos estar únicamente con nosotros mismos, al servicio de la Revolución Socialista.

Para que la América Latina pueda influir en la conservación de la paz y el destino de la civilización es necesario que deje de ser una expresión geográfica y se convierta en una realidad política. Consciente de ellos, el socialismo lucha por la unidad continental, sobre la base de la formación de una economía orgánica antimperialista. La política socialista en la América Latina tiene un doble significado: es el único medio eficaz para la emancipación de las masas obreras y campesinas y la única garantía de nuestra independencia nacional y continental ${ }^{26}$.

Del mismo modo, en esta postura influyó de manera relevante la actitud recelosa que los socialistas populares mostraron a la socialdemocracia europea, pese a los acercamientos realizados por esta en la década de 1950 y la ambigua relación que tuvieron con ella. Ya desde sus orígenes, en la década de 1930 el Partido Socialista había declarado su distancia tanto de la Internacional Comunista como de la Socialista (IS). Si bien hacia el año 1955 los socialistas chilenos participaron en el Comité Consultivo para Latinoamérica, creado por el Bureau del Secretariado Latinoamericano de la IS, el que incluso tuvo su tercera reunión en

\footnotetext{
${ }^{25}$ Este punto ha sido abordado por Joaquín Fermandois, La revolución Inconclusa. La izquierda chilena y el gobierno de la Unidad Popular (Santiago: Centro de Estudios Públicos, 2013) 81-85.

${ }^{26}$ González 88.
} 
Santiago de Chile en 1958, se mantuvieron de manera expresa al margen de la IS. Es más, dicho tímido acercamiento, fue el fruto de un paciente y dificultoso trabajo llevado adelante por los miembros del Bureau con los dirigentes socialistas chilenos, a quienes se les garantizó el recién mencionado status independiente de la Internacional ${ }^{27}$. El mismo Julio Cesar Jobet sostuvo que dicha instancia fue considerada exclusivamente como "una unidad de intercambio informativo y para promover un mayor acercamiento entre todos los partidos socialistas de América Latina, sin necesidad de ser afiliados a la Internacional"28. Por lo demás, la actuación de los socialistas chilenos al interior del Comité Consultivo fue conflictiva, manteniendo fuertes críticas a la socialdemocracia europea, a la que se consideró como cómplice del colonialismo. Las tensiones llegaron a tal punto, que en la percepción del dirigente del Bureau, el socialista uruguayo Humberto Maizategui, el accionar de Chile habría apuntado a realizar una labor de "entrismo", la que habría estado destinada "influir en los restantes partidos y generar una ruptura de estos con la IS"29.

Al tratar la admiración por las experiencias políticas socialistas al margen de la esfera soviética, cabe destacar el creciente interés que desde fines de la década de 1940 comenzó a generar en el Partido Socialista Popular la experiencia socialista yugoeslava, la que fue entendida como un modelo socialista de carácter nacional y autónomo del tutelaje soviético. Desde el año 1948 se hicieron declaraciones de apoyo a Tito y se estrecharon los contactos entre el Partido Comunista de Yugoslavia, más tarde llamado Liga Comunista de Yugoslavos, y el Partido Socialista Popular chileno. Las invitaciones recíprocas, los viajes de delegaciones y las publicaciones políticas de propaganda sobre la experiencia yugoslava, se volvieron recurrentes en el período ${ }^{30}$. En la admiración por el modelo yugoslavo que demostraron los socialistas populares no sólo influyeron el prestigio generado por su eficaz resistencia a la dominación nazi y la autonomía que generó del modelo soviético, sino también los desarrollos teóricos e institucionales que habría generado en favor de dar un "sentido nacional" al marxismo. Fue en este contexto, que el diario La Calle, órgano del Partido Socialista Popular publicó el texto de Boris Ziher, profesor de marxismo en la Universidad de Belgrado, titulado "el Sentido Nacional del Socialismo", señalando que era una "contribución para la aclaración de los problemas que representa la realización del socialismo" ". De la misma manera, los socialistas expresaron admiración por la

\footnotetext{
${ }^{27}$ Olga Ulianova, "Inserción Internacional del socialismo chileno, 1933-1973". Ulianova (editora), 246-251 y Fernando Pedrosa, "La otra izquierda. Estrategias de la socialdemocracia en América Latina 1951-1971". Contemporánea. Historias y problemas del siglo XX 2 (2011) 115-136.

28 Jobet 24-25.

${ }^{29}$ Pedrosa 125. Según la argumentación de Michaell Löwy, en esta situación puede haber influido el que la Internacional Socialista en el período desarrolló una actividad muy limitada hacia América Latina", considerando al subcontinente de manera tácita como una zona de influencia de Estados Unidos", al mismo tiempo que recelaba de las posturas de los socialista chilenos, tendencia que se exacerbó a fines de la década de 1950 con la formación del Frente de Acción Popular, que implicó su alianza con el Partido Comunista, Véase Michael Lowy, “Trayectoria de la Internacional Socialista en América Latina”. Cuadernos Políticos 29 (1981) 40 .

${ }^{30}$ Sobre los nexos entre el socialismo chileno y Yugoslavia véase Ulianova 246-251 y Fermandois 82-83. Quizás la publicación más relevante de divulgación en Chile sobre la experiencia yugoslava haya sido la de Oscar Waiss, Amanecer en Belgrado (Santiago: Prensa Latinoamericana, 1956).

${ }^{31}$ Boris Ziher, "El Sentido nacional del socialismo". La Calle [Santiago] 8 de octubre de 1953.
} 
participación obrera en la administración de las empresas yugoeslavas, la que veían como un mecanismo eficaz para evitar los procesos de burocratización del régimen y como expresión de una "democracia de trabajadores", lo que servía para generar un contramodelo ante la experiencia soviética. Relatando sus experiencias en viaje por Yugoslavia y alabando el sistema de organización en consejos obreros, Oscar Waiss relataba una anécdota:

El sistema desconcierta a los rusos. En una discusión con economistas yugoslavos, los rusos preguntaron cómo podía planificarse la producción dejando tanta libertad a la iniciativa de los Consejos Obreros y las Comunas; los yugoslavos les preguntaron donde era posible encontrar un conjunto de hombres lo suficientemente inteligentes como para resolver dentro de una oficina todas las necesidades de la sociedad"32.

De este modo, junto con la reivindicación de un "sentido nacional" del socialismo; la mantención de la autonomía del movimiento obrero y la crítica a la burocratización del aparato estatal se transformaron en otros elementos claves en la valoración que Waiss y, en general, la dirigencia socialista, tuvieron sobre el modelo yugoeslavo ${ }^{33}$.

Sin embargo, fuera de este vínculo, establecido con un régimen de características claramente socialistas, los dirigentes e intelectuales vinculados al Partido Socialista Popular comenzaron a desarrollar una admiración creciente por experiencias políticas de carácter nacionalista y "popular", no necesariamente socialistas, en diversos países del tercer mundo y en especial en América Latina. El modo en que los partidos y movimientos de carácter reformista, antimperialista y antioligárquico fueron caracterizados por la dirigencia y los intelectuales socialistas no fue unánime y fue variando en el tiempo. En muchos casos, como hizo el recién asumido Secretario General del Partido Socialista Popular, Aniceto Rodríguez en 1953, se referían a ellos como "movimientos de avanzada y revolucionarios", haciendo un llamado a solidarizar con ellos 34 . La noción de partidos o movimientos "de avanzada", utilizada también en reiteradas ocasiones por Eugenio González, convivió y fue crecientemente desplazada a lo largo de la primera mitad de la decada de la décda de 1950 por la de "movimientos" o "partidos" "nacionales y populares". En la utilización del término "nacionalismo popular", ejerció un importante influjo la recepción de la obra "La rebelión de los pueblos débiles" del socialista colombiano de Roberto García Nossa ${ }^{35}$. La obra fue difundida a través de conferencias, reeditada en Chile, y comentada por la la dirigencia socialista tanto a través de la prensa partidaria como de medios externos. Si bien dicho texto, fue leído de manera crítica, ayudó a generar un marco referencial para la comprensión de los movimientos nacionalistas latinoamericanos desde una perspectiva socialista. El libro de García también fue importante en cuanto aportaban argumentos persuasivos para distinguir el "nacionalismo popular" compatible con el socialismo, de otras expresiones

\footnotetext{
${ }^{32}$ Waiss, Amanecer, 40-41.

${ }^{33}$ En sus memorias, Oscar Waiss destaca la relevancia que los acercamientos con los socialistas chilenos habrían tenido para el régimen socialista yugoeslavo, en cuanto habría sido una de las primeras agrupaciones en expresarle solidaridad y demostrar afinidad para con dicho régimen. véase óscar Waiss: Chile Vivo. Memorias de un socialista. 1928-1970 (Madrid: Unigraf, 1986) 109.

34 "Planteamiento del nuevo secretario general del PSP". La Calle [Santiago] 22 de octubre de 1953.

35 Antonio García, La rebelión de los pueblos débiles (Bogotá: Cooperativa Colombiana de Editores, 1950).
} 
nacionalistas consideradas como "chauvinistas". Sin embargo, en su lectura del texto, los socialistas se preocuparon de remarcar la necesidad de dar una conducción socialista a dicho tipo de movimientos:

El socialista colombiano Antonio García, en su reciente libro denominado 'La rebelión de los pueblos débiles' (cuya tesis central merece serios reparos) ha encontrado una excelente definición de la insurgencia continental: nacionalismo popular. Para él, la etapa actual se caracteriza por la 'toma de la causa nacionalista por el pueblo' con el fin de administrar sus propios recursos y dirigir politicamente su propio destino. No se trata, entonces, de un nacionalismo vociferante y chauvinista, 'armado económica y políticamente para la agresión', sino que de un nacionalismo defensivo que reivindica para las masas trabajadoras el usufructo de las riquezas nacionales" [...] "Este nacionalismo popular ha comenzado a encontrar expresiones políticas cuya indefinición teórica refleja la formación heterogénea de su base social. Pero en la misma medida que responde a la realidad oprobiosa del coloniaje, borra la fisonomía política tradicional, tanto en su forma dictatorial como democrática. Esto quiere decir que pierden significación los simples tiranos militares y adquieren jerarquía los demagogos nacionalistas: se opaca un Odría o un Pérez Jiménez y pasan al primer plano los Perón y los Vargas. En la esfera de la relativa democracia continental se esfuman los partidos 'históricos' conservadores, liberales, radicales, demócratas- y surgen con innegable valor los partidos de la Revolución Nacional -Acción Democrática, APRA, Febrerismo, MNR- pero en el fondo de todo el proceso existe un impulso común: la tendencia nacional de los pueblos subyugados por el imperialismo, hecho que no puede ignorarse si se quiere tener una visión exacta de los acontecimientos [...] Los movimientos populares en América Latina están expuestos a todos los riesgos que derivan de una dirección inexperta y débil. Una cosa es buscar un camino propio y derroteros espontáneos y otra muy diferente, es despreciar la doctrina marxista e ignorar las relaciones de fuerza de las diversas clases sociales [...] La finalidad que debemos perseguir es la conjunción entre el nacionalismo popular y el bolchevismo militante, en el sentido de la abnegación y conciencia clasista de los cuadros del viejo partido bolchevique ruso" $" 36$.

Siguiendo esta lógica, los socialistas evidenciaron su admiración por los gobiernos de la Primavera Guatemalteca, bajo el impulso, primero de Arévalo y luego de Arbenz ${ }^{37}$. Durante el período, los socialistas también revitalizaron sus contactos con el Partido Aprista Peruano. Un factor que puede haber influido en el "revival" nacionalista del partido socialista hacia inicios de la década de 1950 puede haber sido la llegada de un nuevo contingente de exiliados apristas, muchos de los cuales se instalaron en Chile desde que se produjo el ascenso de la dictadura de Odría en Perú, en el año 1948, reforzando de este modo las redes y lazos que existían entre el APRA y el socialismo chileno desde la década

\footnotetext{
${ }^{36}$ Ulises, "Nacionalismo popular y socialismo militante". La Calle [Santiago] 27 de septiembre de 1954.

${ }^{37}$ Véase Roberto García Ferreira, "Sumida en las tinieblas: Guatemala, octubre de 1954". Revista de Historia de América 149, (julio-diciembre de 2013) 171-193 y Mark T. Hove, "The Arbenz Factor: Salvador Allende, US-Chile Relations, and the 1954 U.S. Intervention in Guatemala"- Diplomatic History 31. 4 (septiembre 2007) 623-663.
} 
de 1930, al mismo tiempo que las tendencias indoamericanistas que existían al interior de este $^{38}$.

Coetáneamente los socialistas desarrollaron manifestaciones de adhesión hacia los movimientos que libraban guerras de descolonización en Argelia y el Sudeste Asiático y por el nasserismo en Egipto ${ }^{39}$. En un editorial de inicios del año 1952, el periódico La Calle defendía las luchas de descolonización:

Desde el estrecho de Gibraltar hasta el mar de la China, unidos por el hilo invisible de la rebelión anti-imperialista y el repudio de los viejos sistemas coloniales defienden las poblaciones activas de Marruecos, Egipto, Irán, Península Malaya e Indochina el derecho, reconocido en teoría por el mundo de occidente, pero negado en la práctica, del gobierno propio y la nación soberana ${ }^{40}$.

Es en este contexto específico que se explican los crecientes contactos con el MNR y la admiración por el "modelo" boliviano. Durante el período conocido como el "Sexenio" o "Sexenio Rosquero", comprendido entre los años 1946 y 1952, los socialistas populares entraron en contacto con exiliados Trotskistas del Partido Obrero Revolucionario (POR) y del ala izquierda del Movimiento Nacionalista Revolucionario (MNR). En este aspecto, la figura de Juan Lechín, líder de la Federación sindical de Trabajadores Mineros Bolivianos, dirigentes del ala izquierda del MNR y que además mantenía estrechos vínculos con los poristas, jugó un rol fundamental. Durante su exilio en Chile tras el año 1949, Lechín fue invitado a exponer en el Comité Central del Partido y se transformó en un nexo con el MNR. De esta manera, la actitud de los socialistas transitó desde una desconfianza hacia las tendencias "fascistas" que atribuían al MNR, a una crecente admiración por su carácter antimperialista. Las principales políticas emprendidas por la Revolución Nacional Boliviana, durante su primer período, entre 1952 y 1956, como fueron la nacionalización de la minería del estaño, la expansión del sufragio, la reforma agraria y la reforma del aparato militar en favor de las milicias obreras generaron manifestaciones de aprobación de los socialistas, pues veían en ellas la concreción de muchas de sus propias aspiraciones programáticas ${ }^{41}$.

\footnotetext{
${ }^{38}$ En referencia a la revitalización de los contactos con el APRA, véase Hugo Vallenas Málaga, "En la rebeldía hermanos: confluencias peruano-chilenas en las luchas sociopolíticas latinoamericanas (Siglos XIX y XX)", Sergio González Miranda y Daniel Parodi, Las historias que nos unen. Episodios positivos en las relaciones entre Chile y Perú, siglos XIX y XX (Santiago: RIL Editores, 2014) 220-222.

${ }^{39}$ Véase Fermandois 80 y 83-85.

40 "Los pueblos coloniales luchan por su libertad". La Calle [Santiago] 12 de enero de 1952.

${ }^{41}$ Sobre el Sexenio, la situación del trotskismo boliviano y su relación con el MNR véase John S. Sandor, Bolivia's Radical Tradition. Permanent Revoluction in the Andes (Tucson: The University of Arizona Press, 2009): 84-116. Sobre la valoración temprana de la Revolución Nacional Boliviana y sobre los antecedentes de contactos entre el MNR y el PS afines del Sexenio, véase "Orientaciones Socialistas: La Revolución Boliviana". La Calle [Santiago] 19 de abril de 1952. Sobre los exiliados bolivianos en Chile, con énfasis en los poristas, véase Edwin Moller, El Dios desnudo de mi conciencia revolucionaria. Autobiografía y revolución nacional (La Paz: Plural Editores, 2001) 38-39. El propio Juan Lechín Oquendo escribió para la prensa socialista chilena, véase, de su autoría, "La Lección de Bolivia". La Calle [Santiago] 2a Quincena de junio de 1955. Carlos Altamirano recuerda la simpatía que la Revolución Nacional Boliviana generó en el Partido Socialista Popular, especialmente en la figura de Raúl Ampuero. Al respecto véase Gabriel Salazar, Conversaciones con Carlos Altamirano. Memorias críticas (Santiago: Debate, 2011). James Dunkerley ha
} 
Algunos autores han interpretado las tendencias nacionalistas como adhesión al peronismo, remarcando la importancia que en dicho momento habría tenido aquella experiencia argentina como modelo político. Así, Ernest Halperin sostuvo que los socialistas habrían admirado a Perón por su "lucha contra los partidos políticos democráticos, los que eran considerados por ellos como instrumentos de la oligarquía, y también, con algo de razón, por su legislación laborales y el fortalecimiento del movimiento obrero" "42. Con posterioridad Benny Pollack y Hernán Rosenkraz, basándose en los planteamientos de Halperin, sostuvieron que los socialistas habrían visto "en el peronismo una suerte de movimiento de liberación", situación que recién habría venido a cambiar tras el "eclipse" de dicho régimen, cuando se habrían evidenciado sus ambigüedades y los límites en sus afanes por destruir el poder oligárquico ${ }^{43}$. Tendemos a discrepar de dichas visiones y, por el contrario, coincidimos con Olga Ulianova quien ha planteado un juicio más sutil, que refleja más claramente las ambiguiedades y matices de los vínculos entre los socialistas chilenos y el peronismo, al sostener que el discurso socialista del período apelaba a "fuerzas "populares y nacionales', término en uso en la Argentina peronista de la época", lo que podría ser considerado como un "guiño al populismo trasandino" ". Consideramos que antes que una admiración por el peronismo, el que incluso siguió siendo considerado como un movimiento de carácter demagógico y cuyo personalismo generaba desconfianza, primó un análisis estratégico que además de valorar algunas de sus "conquistas" sociales, buscaba comprender las razones de su éxito y su capacidad de movilización popular ${ }^{45}$. Un ejemplo de esta postura puede ser observada en los discursos con que los socialistas populares justificaron su apoyo a la candidatura de Carlos Ibáñez del Campo. En ellos esgrimieron como argumento la similitud entre el ibañismo y el peronismo, y la necesidad de no replicar la experiencia de los socialistas argentinos, los que por su obcecado antiperonismo, habrían sido desplazados de la conducción del movimiento obrero y perdido el apoyo de las "masas". Según diversos dirigentes socialistas, dicha situación se explicaría por las tendencias europeizantes y liberales de la dirigencia socialista argentina, que no les habría permitido comprender el arraigo alcanzado por el peronismo en la población ${ }^{46}$. No es de extrañar que, en este período, los socialistas generaran acercamientos con Acción Socialista, escisión del Partido Socialista argentino dirigida por Dardo Cúneo ${ }^{47}$. Se trataba de un grupo intelectual socialista que devino en partido, el cual, si bien mantuvo una postura crítica del peronismo, al mismo tiempo acusó a la rama central de los socialistas de realizar una oposición basada en la "intriga estéril" y de hacerse parte de una estrategia oligárquica, al mismo tiempo que hacía un llamado a entender la actitud de las masas que habían adherido al peronismo y sus

abordado los efectos que los contactos de los exiliados del MNR con la izquierda generaron en dicho movimiento. James Dunkerley, Rebellion in the veins. Political Struggle in Bolivia 1952-1982 (Londres: Verso, 1984) 35-36.

${ }^{42}$ Ernest Halperin, Nationalism and Communism in Chile (Cambridge: The M.I.T. Press, 1965) 136.

${ }^{43}$ Pollack y Rosenkraz 37

${ }^{44}$ Ulianova 235

${ }^{45}$ Oscar Waiss, Nacionalismo y socialismo en América Latina (Santiago: Prensa Latinoamericana, 1954) 113114.

${ }^{46}$ Almeyda, 124.

${ }^{47}$ Ulianova, 251. 
anhelos de justicia social, para así darles una orientación de carácter socialista ${ }^{48}$. El propio Cúneo asistió como Delegado Invitado al XV Congreso del Partido Socialista Popular, el que tuvo lugar en San Antonio los días 16, 17 y 18 de octubre de 1953.

\section{Difundiendo las experiencias nacionalistas latinoamericanas}

Bajo este impulso, se crearon instancias específicas destinadas a generar vínculos con otras fuerzas nacionalistas latinoamericanas y a difundir las ideas latinoamericanistas en Chile. Ya en 1948, uno de los fundadores del Partido Socialista, y en ese entonces dirigente del Partido Socialista Popular, Federico Klein, participó como impulsor en la creación del Movimiento Pro Unión de Latinoamérica, del cual llegó a ser Secretario General. Se trataba de una instancia que logró congregar a diversos políticos chilenos, en la promoción de los vínculos con los países latinoamericanos ${ }^{49}$. Con posterioridad, en 1955, el mismo Klein, ahora como secretario de Relaciones Internacionales del Departamento Internacional del Partido Socialista Popular, organizó en Santiago un comité formado por "ciudadanos de diversos países latinoamericanos", el que se encontraba destinado a crear la "Casa Latinoamericana". Según la declaración fundacional del comité:

La Casa Latinoamericana será el hogar de cuantos amen la libertad y la justicia y crean en los ideales de libertad que predicaron los padres de la patria. La casa latinoamericana será no sólo el hogar de la confraternidad de nuestra América, sino el asilo generoso para todos aquellos que en otras latitudes han sido privados del derecho a sostener sus principios e ideales ${ }^{50}$.

Las publicaciones periódicas y la industria editorial jugaron un papel relevante en el afán desarrollado por el Partido Socialista Popular en pro de difundir noticias sobre las experiencias políticas de corte nacionalista en Chile y crear contactos con organizaciones políticas latinoamericanas.

En primer lugar, es necesario analizar las publicaciones periódicas del Partido Socialista Popular en ese momento. Cabe mencionar al periódico La Calle, que vió la luz, primero de manera semanal y luego quincenal, entre diciembre de 1949 y el mismo mes del año 1955 y que tuvo el rol de órgano oficical del Partido Socialista Popular, con pretensiones de llegar a un público masivo. Dicho periódico dio un fuerte énfasis a las noticias referentes a movimiento nacionalistas y antimperialistas, además de dar tribuna a

\footnotetext{
${ }^{48}$ Carlos Miguel Herrera, "El intelectual como partido: Dardo Cúneo y la experiencia de Acción Socialista", en Archivos de historia del movimiento obrero y de la izquierda 3 (2013) 35-56.

${ }^{49}$ La semana Internacional [Valparaíso] 21 de febrero de 1948. En efecto, en el acto fundacional participaron dirigentes estudiantiles, sindicales y políticos chilenos, además de miembros del cuerpo diplomático de diversos países latinoamericanos. Entre los políticos chilenos que actuaron como oradores en aquella ocasión se encontraban Juan Bautista Rossetti, Salvador Allende, el propio Federico Klein, todos ellos vinculados a distintas vertientes del socialismo chileno, además del ex presidente Arturo Alessandri Palma, del Partido Liberal, quien a la sazón era presidente del Senado.

50 "La Casa Latinoamericana. Fecunda iniciativa del Departamento Internacional”. Boletín del Comité Ejecutivo del Partido Socialista Popular 2 (diciembre de 1955) 2. En dicha instancia participó el dirigente aprista peruano Luis Alberto Sánchez.
} 
dirigentes de los partidos socialistas y antiimperialistas latinoamericanos y a exiliados de aquellos países residentes en Chile. Una tendencia similiar se denota en las páginas del Boletín del Comité Ejecutivo del Partido Socialista Popular, que estuvo en circulación entre la militancia del Partido entre noviembre de 1955 y el primer semestre de 1957, y que luego, con leves cambios, tuvo continuidad como órgano del Comité Central del Partido Socialista de Chile ya unificado. En sus páginas se dieron claras directrices a la militancia en favor del apoyo a partidos populares de carácter antimperialista y de movimientos de liberación nacional. En mayo de 1954 se creó la revista Nuevos Rumbos, dependiente de un Centro de Estudios Sociales del mismo nombre. Entre sus redactores se encontraban jóvenes socialistas vinculados al ámbito universitario e intelectual, entre ellos Jorge Barría Serón, Eduardo Godoy, Iván Núñez y Violeta Núñez. Se esperaba que uno de sus énfasis fuera la actualidad latinoamericana, particularmente en las luchas antimperialistas y las guerras de liberación nacional. Así, los títulos de la sección internacional del primer número de Nuevos Rumbos fueron: "Guayana Británica: Una prisión”, "Acción Anticomunista, tapadera de intentos turbios", "Preocupación grave para EEUU: Indochina". De un modo similar se planteó de manera explícita que junto con difundir las ideas del "socialismo nacional revolucionario de América Latina", los fines de la revista y el Centro de Estudios Nuevos Rumbos apuntaban a crear las "condiciones propicias para fortalecer una vinculación orgánica entre todas nuestras colectividades, nuestros partidos; para intercambiar importantísimas experiencias y mejorar las condiciones objetivas de nuestra acción”. Con dicho fin, en el equipo de redacción de Nuevos Rumbos "figuraban nombres de jóvenes camaradas que militan en agrupaciones socialistas y afines de prácticamente todos los países latinoamericanos"

En segundo lugar, se debe tener en cuenta el rol que tuvo una nueva editorial vinculada al Partido Socialista, que sintomáticamente recibió el nombre de Prensa Latinoamericana, tuvo en dar a conocer experiencias y autores que se refirieran a la relación entre nacionalismo y socialismo. A inicios del año 1954 Prensa Latinoamericana fue creada bajo el impulso del Partido Socialista Popular y financiada con una campaña de recolección de fondos y colocación de acciones realizada por militantes, sindicatos e intelectuales a lo largo del país ${ }^{52}$. Fue bajo el alero de dicha editorial que, a mediados de la década de 1950 se publicaron dos de los textos más importantes en este sentido, como fueron Nacionalismo y Socialismo en América Latina en 1954 y Amanecer en Belgrado, en 1956, ambos de Oscar Waiss. Cabe mencionar que a poco más de un año de haberse constituido como sociedad, junto con proponerse enriquecer su colección a través de la publicación de autores socialistas chilenos, como el propio Waiss, Julio Cesar Jobet, Raúl Ampuero y Ramón Silva Ulloa, la editorial proyectaba publicar tres títulos. Estos eran La Rebelión de los Pueblos Débiles, del socialista colombiano Antonio García, incluyendo "notas específicas para la edición chilena"; La democracia socialista en la práctica yugoeslava de Edvard Kardelij, intelectual y dirigente da la Liga Comunista de los Yugoslavos, y El Drama de Judas Iscariote, del intelectual antiimperialista dominicano, y posterior presidente de Republica

51 Mario Garay, "Nuevos Rumbos, en la contraofensiva cultural del pensamiento socialista y nacional revolucionario". La Calle [Santiago] 3 de junio de 1944.

52 "Hoy terminan de firmar escritura de prensa latinoamericana S.A.". La Calle [Santiago] 11 de febrero de 1954. 
Dominicana, Juan Bosch ${ }^{53}$. Todos los títulos reflejaban el intento de difundir experiencias y obras de autores proclives a experiencias de socialismos nacionales o "nacionalismos populares".

Tanto las publicaciones periódicas como el esfuerzo editorial desplegado a través de Prensa Latinoamericana pueden ser vistos como parte de una "lucha cultural". Como sostuvo Mario Garay, miembro del comité central del Partido, se trataba de una suerte de "contraofensiva cultural", que pretendía disputar terreno a corrientes que hasta el momento se habían vuelto hegemónicas en el ámbito de las publicaciones políticas e intelectuales, como serían "la inadaptable agitación estalinista, dogmática, torpe, siempre destinada al fracaso, y la agresiva prepotencia imperialista del Departamento de Estado yanqui”, ${ }^{\text {. }}$

\section{Socialismo y nacionalismo en la formulación de nuevos lineamientos estratégicos: El rol de Oscar Waiss}

Sin embargo, la vinculación con modelos políticos de contenido nacionalista y antiimperialistas, pero no necesariamente socialistas, creaba importantes grados de tensión entre la dirigencia y los intelectuales vinculados al Partido Socialista Popular. Dicha situación se volvía aún más acuciante, dado el carácter reciente que aún tenía la memoria de la lucha antifascista, con tendencias antinacionalistas y democrático-liberales que habían visto asociadas a esta. Por este motivo, tanto dirigentes como intelectuales socialistas debieron justificar teóricamente la vinculación entre nacionalismo y socialismo y generar contenidos programáticos a partir de esta.

Fué Oscar Waiss quien se ocupó de manera más sistemática en desarrollar una justificación teórica sobre la vinculación entre nacionalismo y socialismo. A través de columnas en diarios y libros, además de su participación en conferencias y cursos de formación política, Waiss se encargó de elaborar y transmitir un cuerpo doctrinal teóricamente coherente sobre dicho tema, el que alcanzó un alto grado de influencia, siendo citado por otros dirigentes socialistas en ámbitos nacionales e internacionales y utilizado como fundamento en programas y lineas estratégicas.

Polemizando particular y abiertamente con los comunistas chilenos a través de la prensa, y de manera más general con la actitud de los partidos comunistas latinoamericanos, Waiss advirtió contra la tendencia a caracterizar a los "movimientos populares", lationoamericanos como "nacionalismo burgués". A dichas visiones respondió que:

Hubiera sido dificil explicarle que su supuesto internacionalismo era de corte estrictamente idealista - en el peor sentido de la palabra- y que el nacionalismo

\footnotetext{
53 "Próximas publicaciones de Prensa Latinoamericana S.A.". La Calle [Santiago]1 a quincena de junio de 1955. La edición chilena de La rebelión de los pueblos débiles vio la luz en 1958. Véase García, Antonio: La democracia en la teoría y en la práctica y la rebelión de los pueblos débiles. Santiago: Prensa Latinoamericana, 1958. Sobre la industria editorial en el período véase Bernardo Subercaseaux, Historia del libro en Chile. Desde la Colonia hasta el Bicentenario (Santiago: Lom, 2010) 129-173.

${ }^{54}$ Mario Garay, "Nuevos Rumbos, en la contraofensiva cultural del pensamiento socialista y nacional revolucionario". La Calle [Santiago] 3 de junio de 1944.
} 
anti-imperialista de las masas latinoamericanas involucraba un contenido profundo y reivindicativo de positiva tendencia de lucha por el socialismo mundial",55.

Además de sostener, con su mordaz estilo de polemista, que:

En América Latina, donde la evolución social ha sido dislocada por los procesos de superposición de diferentes etapas de progreso material, que han confundido para las mentes simplistas el desarrollo natural de la economía y aún las fronteras entre clases, los intelecutuales y teóricos de pacotilla suelen ser aun más abundantes $^{56}$.

Como puede observarse en los planteamientos recién expuestos, queda explícita una defensa del nacionalismo antimperialista latinoamericano y un intento de situarlo en un esquema de interpretación marxista, adaptado para el contexto latinoamericano. De este modo, en el marco de su crítica al "etapismo" planteado por los comunistas en su concepción revolucionaria, hacía un llamado a valorar las condiciones locales y dentro de ellas el potencial de movilización del nacionalismo ${ }^{57}$. Así podemos ver como en el desarrollo teórico que derivó en la génesis de la línea de frente de trabajadores, el hincapie nacionalista y latinoamericanista jugó un rol fundamental.

Waiss profundizó en dichas concepciones en diversas conferencias y jornadas de formación política que realizó a lo largo del país, en ellas también explicitó las fuentes teóricas desde las que se nutrió para realizar este desarrollo. En dichas instancias analizó textos de "Lenin escritos en 1905 y 1917", al mismo tiempo que citó "la exégesis de Trotsky en la polémica de los años 1923-28”. A través de la interpretación de dichos textos, sostuvo que era posible distinguir las nociones de "dictadura democrática de obreros y campesinos" de la de " dictadura proletaria", fundamentando la inclusión de demandas nacionalistas en objetivos socialista. Estas se expresaron en la noción que Waiss desarrolló de "República Democrática de Trabajadores", explicando sus características distintivas:

Después de señalar la forma que debería tener un gobierno en estos paises y explicar el significado de la República Democrática de Trabajadores, se extendió en explicar los objetivos de este gobierno, indicando especialmente los siguientes; a) Ampliación de la democracia; b) Organización armada del pueblo; c) Reforma Agraria; d) Nacionalización para la sociedad de las riquezas fundamentales y e) Integración económica latinoamericana ${ }^{58}$.

\footnotetext{
${ }^{55}$ Oscar Waiss, "El marxismo y algunos marxistas". La Calle [Santiago], 3 de diciembre de 1953.

${ }^{56}$ Oscar Waiss, "El marxismo y algunos marxistas". La Calle [Santiago], 3 de diciembre de 1953.

57 Estas críticas al "etapismo" se insertan en una tendencia más general, de los intelectuales marxistas latinoamericanos a poner en tensión la interpretación soviética del marxismo, representada principalmente por los partidos comunistas desde mediados de la década de 1930, y que en lo fundamental se mantuvo tras el fin de la Segunda Guerra Mundial. Michael Löwy, "Introducción. Puntos de referencia para una historia del marxismo en América Latina”. Michael Löwy, El marxismo en América Latina. Antología desde 1909 hasta nuestros días (Santiago: Lom, 2015) 21-42.

58 “Carácter de la Revolución Latinoamericana”. La Calle [Santiago] 7 de enero de 1954.
} 
Las ideas de Waiss fueron sintetizadas, finalmente, en el libro Nacionalismo y Socialismo en América Latina, publicado por Prensa Latinoamericana en el año 1954, en el cual sostuvo la necesidad de que los partidos socialistas tomaran la dirección del proceso revolucionario latinoamericano, comprendiendo y valorando la capacidad movilizadora de los movimientos "nacionales y populares", para ser capaces de darle conducción en un sentido socialista. En sus palabras:

No pueden ser capaces de dirigir la revolución y transformar el escenario imperante, partidos que no intentan seriamente gravitar en los movimientos sociales más poderosos (...) No se puede dirigir una cruzada de tanta envergadura ni inspirar confianza en las masas, si se desconoce la dinámica del movimiento y la tarea más importante de estos partidos -también la más difícil- consiste en advertir con precisión las tendencias populares y nacionales para interpretarlas con justeza, en el momento apropiado y con voces de orden, o sea, consignas de lucha, que representen el deseo profundo y las necesidades reales de las mayorías que trabajan ${ }^{59}$.

En ese mismo libro, Oscar Waiss hizo una especial valoración de "las experiencias de Bolivia y Guatemala", sosteniendo que estas iluminan la ruta para los otros pueblos"60.

\section{Una línea política nacional-revolucionaria}

Fue en este contexto de alejamiento del centro político representado en el Partido Radical al mismo tiempo que de acercamiento a experiencias políticas de carácter nacionalista, que el Partido Socialista Popular planteó como uno de sus fines la construcción de un Estado Nacional Revolucionario y definió su "línea política" como "nacional revolucionaria"61. Esta situación tuvo lugar en el XVI Congreso General Ordinario del Partido Socialista Popular, realizado en Valparaíso los días 29, 30 y 31 de octubre de 1955. En aquella ocasión se discutió un documento titulado "La situación Económica Social y las Tareas de la Revolución Chilena". En dicho texto, se denunciaba la gravedad de la "situación social, económica y política por la que pasaba Chile", la que estaría caracterizada por "la detención del proceso de desarrollo económico y de mejoramiento de las condiciones de vida del pueblo". En el escrito, se planteaba que esta situación tendría lugar por la incapacidad de planificar la actividad económica y organizar la vida política del país, debido

\footnotetext{
${ }^{59}$ Oscar Waiss, Nacionalismo, 115.

${ }^{60}$ Oscar Waiss, Nacionalismo, 115.

${ }^{61}$ La enunciación de dicha línea se encuentra en el documento "La situación económico social y las tareas de la Revolución Chilena". Boletín del Comité Ejecutivo del Partido Socialista Popular 1[Santiago] noviembre de 1955, 1-3. Con posterioridad el Comité Ejecutivo del Partido Socialista Popular volvió a insistir en la necesidad de difundir dicha "línea política". Según el boletín de dicha organización : "El comité Ejecutivo tomó nota de la necesidad de iniciar una divulgación intensiva dentro y fuera del Partido, de la línea política nacional revolucionaria, de su fundamentación teórica y de sus raíces en la realidad chilena, para lo cual se deberá dotar a los organismos del Partido del material y de los equipos que se requieran para llevar a cabo esta tarea. Véase las "Conclusiones del debate político del Comité Ejecutivo". Boletín del Comité Ejecutivo del Partido Socialista Popular 8 [Santiago] Julio de 19561.
} 
a la "vigencia de los supuestos (o condiciones) del sistema capitalista en el orden económico y de sus concomitantes en el orden social y político". En este sentido, sindicaban al "predominio de las clases medias" como uno de los causantes de la mantención de dicho escenario, por su incapacidad de afectar las bases del sistema económico y social vigente", pese a sus "anhelos progresistas". Así, los socialistas se plantearon en oposición ante otras posturas que también buscarían romper el equilibrio vigente en pos de otros intereses de clase. Una de ellas sería "la derecha", que aspiraría a "frenar el proceso de industrialización promovido por el Estado" y "detener el ritmo de ascenso en las condiciones de vida de las masas", para de este modo, incentivar la "capitalización privada" y las inversiones extranjeras". Otra solución sería la "sustentada por la Clase Media", que apuntaría a mantener las "condiciones capitalistas vigentes, en el orden económico, demo-liberales en el orden político e individualistas en el orden social" ${ }^{62}$. Sostenían que la única solución "verdaderamente progresista y revolucionaria", que lograría "acelerar el actual ritmo de desarrollo económico", consistiría en la que orientara a éste "en el sentido de satisfacer las necesidades sociales" a través de la "planificación económica" ${ }^{63}$. Según el documento:

El desarrollo social configurado de acuerdo con esas directivas, solo puede promoverse si se altera la estructura y supuestos ideológicos liberales del actual Estado Burgués y se construye un Estado Nacional Revolucionario, intérprete confeso de las aspiraciones progresivas de la sociedad, organizador de toda la vida nacional sobre nuevas bases ideológicas de carácter socialista, abandonando todo lastre de conceptos, actitudes y prejuicios de raíz individualista, que no juegan ningún papel constructivo en las nuevas condiciones sociales ${ }^{64}$.

En el mismo documento, sostuvieron que:

El desarrollo de esta política toma en cuenta las condiciones mundiales en que se desenvuelve la pugna del imperialismo yanqui por IMPONER SU PROPIO SISTEMA DE VIDA al resto del mundo, contrariando a los MOVIMIENTOS NACIONALES LIBERTADORES, se coloca al lado de estos últimos y supone, para el éxito definitivo, la inserción del esfuerzo chileno en el proceso liberador y unificador de América Latina, que toma diversas formas en los distintos países, según sea su grado de desarrollo económico, pero que en su conjunto asume el carácter de un movimiento nacional de liberación, interesado en el desarrollo de nuestras fuerzas productivas a través de la liquidación de las oligarquías sirvientes del imperialismo y sus aliados capitalistas y feudales, en la complementación política y económica de nuestros veinte países ${ }^{65}$.

Para con posterioridad recomendar, como medida de acción inmediata: "Reafirmar la independencia recíproca de todos los movimientos nacionales de liberación de América

\footnotetext{
62 "La situación económico social y las tareas de la Revolución Chilena”, en Boletín del Comité Ejecutivo del Partido Socialista Popular 1 [Santiago] noviembre de 1955 1-3

${ }^{63}$ La situación económico social 2

${ }^{64}$ La situación económico social 3

${ }^{65}$ La situación económico social 2-3. Las mayúsculas están presentes en el documento original.
} 
Latina en función del Desarrollo Económico del Continente y su progresiva integración económica y política",66.

\section{Conclusiones}

A incios de la década de 1950, el Partido Socialista Popular no sólo vivó un acercamiento hacia fuerzas nacionalistas en el ámbito nacional, ampliamente representadas en la coalición ibañista de la que formó parte, sino que también puso especial atención a movimientos, partidos y gobiernos de caracter nacionalista en el ámbito internacional.

Los socialistas fijaron su atención en las lecciones que se podían extraer de experiencias políticas extranjeras de caracter antimperialista, entre las que se englobaban los regímenes socialistas con un marcado tinte nacionalista y autonomía de la Unión Soviética como era el caso de Yugoslavia-, los movimientos de descolonización en Asia y África y los movimientos y partidos "nacionalistas populares" latinoamericanos.

La dirigencia del Partido Socialista Popular emprendió una labor de difusión de los modelos políticos extranjeras funcionales a su nuevo proyecto. Así se encargó de dar a conocer, tanto entre su militancia como entre un público masivo, las recién mencionadas experiencias antiimperialistas. Con dicho fin, fuera de la oratoria de sus parlamentarios y dirigentes, se valió de sus órganos de prensa ya existentes, generó medios nuevos e incursionó en la industria editoral. A través de dichas instancias también pretendía reforzar contactos con agrupaciones políticas de corte antimperialista, especialmente en América Latina. En este aspecto, incluso llegaron a crearse instituciones destinadas a reforzar los vínulos con aquellos partidos, como fue el caso de la "Casa Latinoamericana", en las que se asignó un rol protagónico a exiliados residentes en Chile. Estas instancias fueron asumidas por los socialistas como parte de una "contraofensiva cultural", que les permitiría dar a conocer alternativas políticas a los modelos estadounidense y soviético que hasta el momento habrían copado los circuitos político-culturales nacionales. Así, los socialistas chilenos buscaron mostrar que el período de postguerra estaría marcado por la conflagración entre el Norte y el Sur, buscando mantener su autonomía en el conflicto entre Este y Oeste.

La inclusión de experiencias tan diversas en la gama de modelos de internacionales en lo cuales fijó su atención la intelectualidad socialista y, especialemnte, el carácter no socialista de varias de aquellas experiencias políticas, obligaron a los socialistas a desarrollar una justificación teórica, que les permitiera discernir cuales de aquellas experiencias tendrían un valor modélico y como deberían ser afrontadas por un partido de carácter socialista y marxista.

Con dicho fin se utilizaron ideas cuya presencia tenía una larga data en la historia del Partido Socialista Popular, al mismo tiempo que se dió importancia a nuevos autores que interpretaran la situación internacional de la década de 1950. Si bien desde la década de 1930 la presencia de las ideas indoamericanistas vinculadas al aprismo cumplía un rol relevante en el acervo ideológico y el imaginario político de los socialistas chilenos, en la

\footnotetext{
${ }^{66}$ La situación económico social 3.
} 
década de 1950 se recurrió también a otros cuerpos de ideas para justificar la mixtura entre nacionalismo y socialismo. Las ideas del colombiano Antonio García en torno a la valoración positiva de de un "nacionalismo popular" latinoamericano, no "chauvinista" y con un fuerte potencial antiimperialista, permitieron la adopción de una concptualización que que sirviera para nominar a los movimientos políticos antiimperialistas latinoamericanos, distinguiendo aquellos con un potencial de movilización socialista. Los desarrollos teóricos del período, generados mediantes escritos, conferencias y polémicas también dieron un rol relevante al leninismo, incluyendo también a sus variantes trotskistas, como un método de interpretación que permitiera comprender un contexto histórico específico, en este caso de caracter nacionalista, para desarrollar en el las lucha por el socialismo. La gran aspiración de los socialistas era dar un sentido socialista a las reivindicaciones nacionalistas y antioligárquicas presentes en la América Latina de mediados del siglo XX. Así, muchas de las principales elaboraciones teóricas que surgieron en el período se propusieran valorar el potencial socialista del "nacionalismo popular", a la vez que promovían una política que evitara adoptar de manera mecanicista las secuencias propias del "etapismo" en los programas revolucionarios y recelaban su posible burocratización. No es de extrañar que en este proceso de discusión y construcción teórica haya tenido un rol relevante Oscar Waiss, quien provenía de una matriz ideológica trotskista.

Es por esto que el proceso de radicalización de los socialistas chilenos, cuyos orígenes se encuentran a fines de las administraciones radicales, tuvo en sus orígenes un caracter nacionalista revolucionario. Hacia el año 1955, cuando el Patido Socialista Popular se propuso por primera vez la linea estratégica del Frente de Trabajadores, su dirigencia insistió en que las líneas estratégicas del partdo tenían un carácter nacionalista revolucionario y que apuntaban a crear un" Estado Nacional Revolucionario".

\section{Bibliografía}

\section{Fuentes Primarias}

\section{Periódicos y revistas}

- Boletín del Comité Ejecutivo Popular del Partido Socialista Popular [Santiago] 1955-1957.

- La Calle [Santiago] 1949-1955.

- El Mercurio [Santiago] 1951.

- La semana Internacional [Valparaíso] 1948.

\section{Folletos y libros políticos}

- Chelén Rojas, Alejandro: Trayectoria del socialismo. Apuntes para una historia crítica del socialismo chileno. Buenos Aires: Editorial Astral, 1967.

- García, Antonio: La rebelión de los pueblos débiles. Bogotá: Cooperativa Colombiana de Editores, 1950.

- García, Antonio: La democracia en la teoría y en la práctica y la rebelión de los pueblos débiles. Santiago: Prensa Latinoamericana, 1950. 
- González Rojas, Eugenio. "Fundamentación teórica del programa del Partido Socialista". Julio César Jobet y Alejandro Chelén Rojas: Pensamiento teórico y político del Partido Socialista. Santiago: Editorial Quimantú, 1972.

- Waiss, Oscar: Amanecer en Belgrado. Santiago: Prensa Latinoamericana, 1956.

- Waiss, Oscar: Nacionalismo y socialismo en América Latina. Santiago: Prensa Latinoamericana, 1954.

\section{Memorias y entrevistas}

- Almeyda, Clodomiro: Reencuentro con mi vida. Santiago: Las Ediciones del Ornitorrinco, 1987.

- Moller, Edwin: El Dios desnudo de mi conciencia revolucionaria. Autobiografía y revolución nacional. La Paz: Plural Editores, 2001.

- Salazar, Gabriel: Conversaciones con Carlos Altamirano. Memorias críticas. Santiago: Debate, 2011.

- Waiss, Oscar: Chile Vivo. Memorias de un socialista. 1928-1970 (Madrid: Unigar, 1986)

\section{Bibliografía}

- Arrate, Jorge y Eduardo Rojas: Memoria de la Izquierda Chilena. Santiago: Ediciones B, 2003.

- Bourdieu, Pierre: "The social conditions of the international circulation of ideas". Richard Shusterman, Bourdieu. A critical reader. Oxford: Blackwell Publishers, 1999.

- Brands, Hal: Latin America's Cold War. Cambridge, Massachussets \& London: Harvard University Press, 2010.

- Casals Araya, Marcelo: La creación de la amenaza roja. Del surgimiento del anticomunismo en Chile a la "campaña del terror" de 1964. Santiago: Lom Ediciones, 2016.

- Casals Araya, Marcelo: El alba de una revolución. La izquierda y la construcción estratégica de la vía chilena al socialismo. 1956-1970. Santiago: Lom Ediciones, 2010.

- Drake, Paul: Socialism and Populism in Chile, 1932-1952. Chicago-Londres: University of Chicago Press, 1978.

- Dunkerley, James: Rebellion in the veins. Political Struggle in Bolivia 1952-1982. Londres: Verso, 1984.

- Etchepare Jensen, Jaime Antonio: "Ibáñez y su revolución de 1952". Política 26 (1991).

- Faúndez, Julio: Marxism and Democracy in Chile. From 1932 to the Fall of Allende. New Haven: Yale University Press, 1988.

- Fermandois, Joaquín: La revolución Inconclusa. La izquierda chilena y el gobierno de la Unidad Popular. Santiago: Centro de Estudios Públicos, 2013.

- Fernández Abara, Joaquín: "Populismo, democracia y marxismo: el debate de la izquierda chilena y la candidatura presidencial de Salvador Allende en 1952". Finis Terrae, Revista de Humanidades 1, Tercera época (2013).

- Fernández Abara, Joaquín: El ibañismo. 1937-1952. Un caso de populismo en la política chilena. Santiago: Ediciones del Instituto de Historia de Pontificia Universidad Católica de Chile, 2007. 
- Fernández Carroza, Camilo y Pablo Garrido González: “Progresistas y revolucionarios: el Frente de Acción Popular y la Vía Chilena al Socialismo, 1956-1967”. Izquierdas 31 (Diciembre de 2016).

- Halperin, Ernest: Nationalism and Communism in Chile. Cambridge: The M.I.T. Press, 1965.

- Harmer, Tanya: Allende's Chile and the interamerican Cold War. Chapell Hill: The University of North Carolina Press, 2011.

- Hernández Toledo, Sebastián: "Apristas en Chile: circuitos intelectuales y redes políticas durante los años 1930”. Revista de Historia y Geografía 31 (2014).

- Hobsbawm, Eric: Nations and Nationalism Since 1780. Programme, Myth, Reality. Cambridge: Cambridge University Press, 1990.

- Hove, Mark T.: "The Arbenz Factor: Salvador Allende, US-Chile Relations, and the 1954 U.S. Intervention in Guatemala". Diplomatic History 31-4, september 2007

- Huneeus, Carlos: La guerra fría chilena. Gabriel González Videla y la Ley Maldita. Santiago: debate, 2009.

- Jobet, Julio César: El Partido Socialista de Chile. Santiago: Ediciones Prensa Latinoamericana, 1971.

- Löwy, Michael: "Trayectoria de la Internacional Socialista en América Latina". Cuadernos Políticos 29 (Julio-Septiembre de 1981).

- Löwy, Michael: El marxismo en América Latina. Antología desde 1909 hasta nuestros días. Santiago: Lom, 2015.

- Miguel Herrera, Carlos: "El intelectual como partido: Dardo Cúneo y la experiencia de Acción Socialista". Archivos de historia del movimiento obrero y de la izquierda 3 (2013).

- Monsálvez Araneda, Danny: "La historia reciente en Chile. Un balance desde la nueva historia política". Historia 369 6:1(2016).

- Moraga Valle, Fabio: “¿Un partido indoamericanista en Chile? La Nueva Acción Pública y el Partido Aprista Peruano”. Histórica 33.2 (2009).

- Moulian, Tomás: Fracturas. De Pedro Aguirre Cerda a Salvador Allende (1938-1973). Santiago: Lom, 2006.

- Moyano Barahona, Cristina: "La historia política en el Bicentenario. Entre la historia del presente y la historia conceptual. Reflexiones sobre la Nueva Historia Política". Revista de Historia Social y de las Mentalidades 15:1 (2011).

- Ortega Martínez, Luis: “La radicalización de los socialistas de Chile en la Década de 1960. Universum 23. 2 (2008).

- Pedrosa, Fernando: "La otra izquierda. Estrategias de la socialdemocracia en América Latina 1951-1971”. Contemporánea. Historias y problemas del siglo XX. 2, 2011.

- Pollack, Benny y Hernán Rosenkraz: Revolutionary Socialdemocracy: The Chilean Socialist Party. Londres, Pinter, 1986.

- Reveco, Juan Manuel: "La Influencia del APRA en el Partido Socialista de Chile". Igualdad y Democracia 2 (2015).

- Riquelme Segovia, Alfredo: "La Guerra Fría en Chile: Los intrincados nexos entre lo nacional y lo Global". Tanya Harmer y Alfredo Riquelme Segovia (Editores), Chile y la Guerra Fría Global. Santiago: Instituto de Historia de la Pontificia Universidad Católica de Chile -RIL Editores, 2014.

- Roberto García Ferreira: "Sumida en las tinieblas: Guatemala, octubre de 1954", en Revista de Historia de América $\mathrm{N}^{\mathrm{o}}$ 149, México D.F, julio-diciembre de 2013, pp. 171-193. I 
- Rubio Apiolaza, Pablo: "La izquierda Chilena en la década de 1950. Socialistas, comunistas y sus contradicciones". Revista Palimpsesto 1 (2003).

- Sandor, John S.: Bolivia's Radical Tradition. Permanent Revoluction in the Andes. Tucson: The University of Arizona Press, 2009.

- Struck, Bernhard, Kate Ferris y Jacques Revel: "Introduction: Space and Scale in Transnational History". The International History Review 33:4 (2011).

- Subercaseaux, Bernardo: Historia del libro en Chile. Desde la Colonia hasta el Bicentenario. Santiago: Lom, 2010.

- Te Velde, Henk: "Political Transfer: An Introduction". European Review of History 12, (Julio de 2005).

- Ulianova, Olga: "Inserción Internacional del socialismo chileno, 1933-1973". Olga Ulianova (editora), Redes políticas y militancias. La historia política está de vuelta, Santiago: USACH-Ariadna, 2009.

- Vallenas Málaga, Hugo: "En la rebeldía hermanos: confluencias peruano-chilenas en las luchas sociopolíticas latinoamericanas (Siglos XIX y XX)". González Miranda, Sergio y Daniel Parodi: Las historias que nos unen. Episodios positivos en las relaciones entre Chile y Perú, siglos XIX y XX. Santiago: RIL Editores, 2014. 